Western University Scholarship@Western

Biology Publications

Biology Department

Summer 6-2013

\title{
Overwintering in New Zealand stick insects
}

Alice B. Dennis

Landcare Research, Auckland, New Zealand, dennisa@landcareresearch.co.nz

Luke T. Dunning

Landcare Research, Auckland, New Zealand

Christopher J. Dennis

Brent J. Sinclair

Western University, bsincla7@uwo.ca

Thomas R. Buckley

Landcare Research, Auckland, New Zealand

Follow this and additional works at: https://ir.lib.uwo.ca/biologypub

Part of the Biology Commons, Entomology Commons, and the Other Ecology and Evolutionary Biology Commons

\section{Citation of this paper:}

Dennis, Alice B.; Dunning, Luke T.; Dennis, Christopher J.; Sinclair, Brent J.; and Buckley, Thomas R., "Overwintering in New Zealand stick insects" (2013). Biology Publications. 78.

https://ir.lib.uwo.ca/biologypub/78 


\section{Overwintering in New Zealand stick insects}

2

3

4 Alice B. Dennis ${ }^{1,2 *}$, Luke T. Dunning ${ }^{1,2,3}$, Christopher J. Dennis ${ }^{4}$, Brent J. Sinclair ${ }^{5}$ and 5 Thomas R. Buckley ${ }^{1,2,3}$

6

$7 \quad{ }^{1}$ Landcare Research, Private Bag 92170, Auckland, New Zealand

$8 \quad{ }^{2}$ Allan Wilson Centre for Ecology and Evolution

$9 \quad{ }^{3}$ School of Biological Sciences, The University of Auckland, Auckland, New Zealand

${ }^{4}$ 3B Kotiri St, St. Heliers, Auckland 1071, New Zealand

${ }^{5}$ Department of Biology, University of Western Ontario, London, ON, Canada

*Corresponding Author: dennisa@landcareresearch.co.nz. Landcare Research, Private Bag

92170, Auckland, New Zealand. Tel: +64 (09) 574 4194, Fax: +64 (09) 5744101. 


\section{Abstract:}

Stick insects are found in a variety of habitats throughout New Zealand, including at least four species that occur at high altitudes. Here they face physiological challenges that differ from their typically warmer lowland habitats, but their strategies to deal with harsh winter conditions are not known. Autumn and winter field surveys, coupled with caging experiments, were conducted to determine which life stages are overwintering in montane and lowland habitats. Data loggers were placed for approximately one year at each site to measure the leaf litter and canopy microhabitat temperatures. From this, we have found that alpine and lowland stick insects persist in a variety of life stages throughout the year despite multiple exposures to freezing temperatures.

Keywords: Insect cold tolerance, microclimate, Phasmatodea, Niveaphasma annulata, Micrarchus 


\section{Introduction}

Alpine habitats in New Zealand are relatively young (5 Ma), biologically diverse and contain representatives of all major insect lineages (Buckley \& Simon 2007; Wharton 2011). To survive in this harsh environment, many insects have evolved a suite of physiological and biochemical adaptations. The best studied examples of this are the New Zealand alpine weta (Hemideina maori (Pictet \& Saussure)) and the alpine cockroach (Celatoblatta quinquemaculata Johns) (Wharton 2011). Both of these species adopt the most common cold tolerance strategy in the southern hemisphere, freeze tolerance (Sinclair et al. 2003; Wharton 2011). However, the overwintering strategies of many other insects found at high altitudes in New Zealand have not been studied, and it is likely that other species are biochemically, evolutionary or ecologically constrained to avoid freezing through supercooling rather than tolerating internal ice formation (Sinclair et al. 2003).

At least four species of stick insect are found in montane habitats of the South Island of New Zealand (Dunning et al. 2013; Jewell \& Brock 2002; O'Neill et al. 2009; Salmon 1991). Although nothing is known of their overwintering strategies, specimens in the New Zealand Arthropod Collection (NZAC) of mature adults and nymphs of Niveaphasma annulata (Hutton) and Micrarchus Carl have been collected above the tree line in spring and early summer, suggesting that they may have persisted there through winter. However, before investigating cold tolerance strategies in these stick insects, we must first determine the selective pressures that they face throughout the year, and the life stages that are present during the coldest months.

In other parts of the world, records of alpine stick insects are scant, with most Phasmid diversity occurring in lowland tropical forests of Southeast Asia and Central and South America (Otte \& Brock 2005). High altitude stick insects are known from the Andes of South America, but nothing is known about their physiology or the microclimates they occupy. This includes the genera Agathemera Stål, Peruphasma Conle \& Hennemann and Monticomorpha Conle \& Hennemann. Peruphasma marmoratum Muranyi has been collected in the Venezuelan Andes at altitudes between 4,000 and 4,700 metres and may be an obligate alpine species. The genus Agathemera contains a number of species, some found in low altitude forests and some over 4,000 metres (Vera et al. 2012). In North America, the stick insect Dicepheromera femorata occurs at latitudes where winter temperatures are often below freezing for extended periods of the winter (B.J. Sinclair \& M.L. McFarlane, unpublished observations). D. femorata overwinter as eggs (Giese \& Knauer 1977), a common strategy 
among insects (Danks 2007; Rochefort et al. 2011). Overwintering insect eggs uniformly avoid freezing by supercooling (Sinclair et al. 2003).

In New Zealand, high altitude populations are reported from the genera Micrarchus, Niveaphasma and Tectarchus Salmon. The first montane species, Micrarchus nov. sp. 1 (NZAC voucher NZAC03000433), is restricted to the Kaikoura region of the South Island, where it has been collected from sea level to $1105 \mathrm{~m}$ (Mt. Fyffe). Its host plants include Leptospermum scoparium, Kunzea ericoides, Muehlenbeckia sp., and Rubus spp. As it has been recorded over a large altitudinal range, we consider it an ecological generalist.

The second observed montane species is referred to as Micrarchus nov. sp. 2 (NZAC03009458). Previously, it was incorrectly described by Salmon (1991) as Mimarchus tarsatus Carl, however, this name is a junior synonym of Argosarchus horridus (White) as established by Jewell and Brock (2002), and morphological and molecular studies now demonstrate it belongs in the genus Micrarchus Carl. It is commonly collected from Leptospermum scoparium, Traversia baccharoides, Muehlenbeckia axillaris, Dracophyllum rosmarinioides and Gahnia spp. Its range is restricted to Northwest Nelson, Nelson Lakes and Northern Westland (Salmon 1991; Dunning \& Buckley unpublished observation). Micrarchus nov. sp. 2 has been collected as low as 650 metres on the Denniston Plateau, Westland and as high as 1400 metres on Mount Robert, Nelson Lakes National Park. Most records are between 900 and 1,300 metres in elevation and above the tree line; we therefore regard this species as a montane obligate.

Niveaphasma annulata (Hutton) is the third species to be found at high altitudes. Like Micrarchus nov. sp. 1 it is found in lowland habitats and we thus consider it a habitat generalist (Jewell \& Brock 2002; O'Neill et al. 2009). Niveaphasma annulata has been collected from coastal areas just above sea level to the alpine zone up to 1,300 metres from Arthur's Pass National Park to coastal areas of the Southern South Island (Jewell \& Brock 2002; O'Neill et al. 2009). This species appears to be absent from coastal and lowland Canterbury, Westland and the wetter areas of the Southern Alps. Niveaphasma annulata is commonly collected from Leptospermum scoparium, Muehlenbeckia complexa, M. axillaris, Pimelea sp. and Rubus spp. It is a geographic parthenogen with both sexual and asexual alpine populations (O'Neill et al. 2009). In contrast, both montane Micrarchus species always occur in sexual populations.

The fourth species to occur in montane areas is Tectarchus salebrosus (Hutton), which is found as high as 1,100 metres on the Seaward Kaikoura Range and close to sea level near Christchurch. This species has a broad altitudinal distribution, like N. annulata and 
Micrarchus nov. sp. 1, but we did not conduct winter collections of this species and so we do not consider its ecology here.

To investigate whether N. annulata, Micrarchus nov. sp. 1 and Micrarchus nov. sp. 2 survive the winter as adults or as nymphs, we use both field cages and manual surveying in lowland and montane sites on the South Island of New Zealand. We also recorded microhabitat temperatures at each site to better understand abiotic selective pressures experienced by these species. These ecological data are key to determining the overwintering strategies of stick insects in New Zealand.

\section{Methods}

\section{Data loggers}

Temperature was measured at each site beginning in February and March 2011. Temperature recordings were made every $1.5 \mathrm{~h}$ using iButton thermochron data loggers (CD1992L, Maxim-Dallas Semiconductor) housed in rain covers made of $\sim 40 \mathrm{~mm}$ deep plastic cups open at one end (Figure 1). All loggers were placed out of direct sunlight and recorded for approximately one year, with the exception of Puhi Puhi, where temperature was only recorded from July 2011 to January 2012. At six sites (Sewell Peak, Mt. Arthur, Puhi Puhi, Seaward Moss, Nevis Rd., and Coach Rd) there was sufficient leaf litter at the base of the host plant to potentially shelter stick insects, and we buried data loggers here. These were paired with loggers placed in the centre of the plant canopy, between $0.5 \mathrm{~m}$ and $1.0 \mathrm{~m}$ high. In total three sets of paired loggers were deployed at each site. At the remaining sites (Ohau, Remarkables and Dunedin), there was insufficient leaf litter, therefore three solitary loggers were placed in a shielded location near the ground below three separate host plants. From these measurements, the mean temperature, mean daily average high and low, absolute high and low temperature, and number of recordings below $0^{\circ} \mathrm{C}$ were calculated for each month using R (R Development Core Team 2012). At sites with paired loggers, we tested for differences between the annual minimum and annual maximum temperatures in the canopy and leaf litter using a one-sided Wilcoxon signed-rank test implemented in R.

\section{Collections}

References to undescribed species follow the recommendations in Leschen et al. (2009). We surveyed winter survivorship in N. annulata, Micrarchus nov. sp. 1, and. Micrarchus nov. sp. 
2. Collection locales (Table 1, Figure 2) were chosen for their abundant summer (January March) populations; in 2011 more than 50 individuals were observed at all sites in one or two nights (between 1 and 6 hours surveying). In summer 2012, we again found abundant populations at each site, indicating that the winter absences we report here were not permanent.

Winter field observations of N. annulata, Micrarchus nov. sp. 1 and Micrarchus nov. sp. 2 were conducted in April and July 2011 (Table 1). Insects were collected by eye ( $N$. annulata) or by eye and using beat sheets (Micrarchus). All searches were conducted for 1.5 $\mathrm{h}$ to $4 \mathrm{~h}$, and where live food plant could be located (i.e. this was not prevented by snow cover) this included a night collection, beginning at least one hour after dark.

\section{Caging}

In April 2011, N. annulata were placed into a cage at each of two field sites (Table 1). Cages were constructed of nylon insect mesh supported by plastic piping (Figure 1). These were anchored to the ground so that the entire host plant and surrounding ground vegetation was contained. At Seaward Moss, one cage enclosed an approximately 1 meter high $L$. scoparium. At Ohau, a slightly smaller cage enclosed a small Rubus sp. (bush lawyer). Cages were revisited and thoroughly inspected for insects in both the foliage and ground vegetation in July 2011.

\section{Results and Discussion}

\section{Microhabitat temperatures}

Across all sites, sub-zero temperatures were recorded at least once in between two and 12 months of the year (Table 2,3). However, summer freezing incidences were rare. January, for example, had only two early morning freezing instances (lasting between 1.5 and 4.5 hours) at one alpine site (Nevis Rd., $-0.1^{\circ} \mathrm{C}$ ) and two freezing instances at one lowland site (Seaward Moss, $-1.4^{\circ} \mathrm{C}$ ). Mean temperatures in January ranged from $+9.8^{\circ} \mathrm{C}$ at Mt. Arthur to $+15.6^{\circ} \mathrm{C}$ at Kaikoura.

Winter temperatures were cooler, with mean July temperatures ranging from $+0.5^{\circ} \mathrm{C}$ (leaf litter, Mt Arthur and Nevis Rd.) to $+4.5^{\circ} \mathrm{C}$ (litter and at the ground, Seaward Moss and Dunedin). At Mt. Arthur, snow buffered the temperatures for an extended period, and temperature recorded by the data loggers was stable around $0^{\circ} \mathrm{C}\left(+/-2^{\circ} \mathrm{C}\right)$ from 6 July to the 
30 August in 2011. During this time, temperatures were warmer than the other montane sites, and some lowland sites (Figure 3,4). To a lesser extent, snow cover at the Remarkables also reduced daily temperature fluctuations in winter.

Montane and lowland populations of $N$. annulata are genetically similar (Jewell \& Brock 2002; O'Neill et al. 2009), thus we expect that all populations have the ability to survive similar conditions. In fact, the winter temperatures at some of the lowland sites can be nearly as cold as the montane sites. Seaward Moss (elevation 9m) had between two and 45 monthly freezing measures, and was the only site at which temperatures below freezing were recorded in all 12 months of the year (Table 3). Additionally, Seaward Moss had an average daily low canopy temperature of $+1.0^{\circ} \mathrm{C}$ in July, and an absolute minimum temperature of $-6.7^{\circ} \mathrm{C}$ in October (Figure 4). Although more freezing recordings were taken at montane sites, this was the coldest measurement anywhere in October, and demonstrates that overwinter survival in exposed lowland populations of $N$. annulata also requires adaptation to the cold. In contrast to N. annulata, lowland populations of Micrarchus nov. sp. 1 (Table 2) collected at Puhi Puhi experienced relatively warm conditions, with mean July temperatures $\left(+3.6^{\circ} \mathrm{C}\right.$ litter, $+3.7^{\circ} \mathrm{C}$ canopy) several degrees above those at Mt. Arthur $\left(+0.5^{\circ} \mathrm{C}\right.$ litter, $+0.3^{\circ} \mathrm{C}$ canopy), although closer to those at Sewell Peak $\left(+2.8^{\circ} \mathrm{C}\right.$ litter, $+2.7^{\circ} \mathrm{C}$ canopy). Incidences of freezing were also lower at Puhi Puhi in July (6-20, compared to 34 -106 at Mt. Arthur and Sewell, Table 2). Thus, in Micrarchus, lowland populations may experience less selective pressure to tolerate freezing than montane populations.

There was also evidence of thermal buffering in the leaf litter. In the canopy, minimum annual temperatures were significantly colder $(\mathrm{W}=0,11 \mathrm{df}, \mathrm{p}=0.016)$ and maximum annual temperatures were significantly warmer $(\mathrm{W}=21,11 \mathrm{df}, \mathrm{p}=0.016)$ than the leaf litter. Monthly extreme temperatures were generally buffered in the leaf litter by $1-3^{\circ} \mathrm{C}$, with this being most obvious at colder sites (Seaward Moss, Nevis, Sewell Peak and Mt. Arthur). There were also more sub-zero events in the canopy than the litter (Table 2, 3). Thus, except for extended cold periods, the litter at the base of the plants provides a habitat with less extreme temperatures than the canopy above. This microhabitat selection could be key to surviving both biotic and abiotic challenges in the environment (Sinclair 2001), but it is difficult to determine if this amount of thermal buffering is physiologically relevant. For example, in insects inhabiting tree bark microhabitats, thermal buffering may not be sufficient to provide a physiological benefit (Vermunt et al. 2012).

\section{Caging}


Despite temperatures that had already fallen to $-2.4^{\circ} \mathrm{C}$, three nymphs out of the 25 stick insects that were caged in the autumn were located in winter at Ohau (Table 1). At Seaward Moss, both nymphs and adults were found in the cage, despite temperatures at this lowland site having reached $-6.0^{\circ} \mathrm{C}$ prior to collection. We also only recovered a portion of the caged individuals at Seaward Moss (14 placed, four recovered). The lower numbers of individuals recovered from both cages suggests that winter populations may be reduced relative to those found in the summer, but these collections show that both alpine and lowland $N$. annulata remain alive in the field despite being exposed to freezing conditions.

\section{Autumn collections}

In April, stick insects of all life stages were recorded at five of the six sites visited (Table 1). This included both alpine and lowland populations of N. annulata, and the sole Micrarchus site visited (Micrarchus nov. sp. 1, Puhi Puhi, lowland). The only site at which successful autumn collections were not made was the montane population at the Remarkables. This is possibly due to grass cover reducing the abundance of known food plants (Pimelia sp., Muelenbeckia complexa and Rubus sp.). It is unknown whether the insects had shifted to another host plant, or if they were only present as eggs.

\section{Winter collections}

In July, both adults (male and female) and late instar nymphs were actively moving around their host plants at five of the nine sites visited. Niveaphasma annulata was found at one of the three montane sites (Ohau, Table 1). We did not locate any individuals at the Remarkables or Nevis Rd, perhaps due to dense snow cover on the host plants (Pimelea sp. and Rubus sp., respectively). At both sites, we were able to remove snow and locate live plants, but the likelihood of doing so in a spot that happened to have a visible insect is low. Therefore, we could not determine if snow cover excluded adults and nymphs from this site during the winter or if it only made collection difficult. At Ohau there was less snow cover, and healthy host plants (Rubus sp.) were exposed during our collections. Here, we observed both adults and nymphs actively moving, and presumably feeding, at night, despite air temperatures of $+3.5^{\circ} \mathrm{C}$ during collection.

Active individuals of $N$. annulata were also located at two of three lowland sites (Seaward Moss and Dunedin, Table 1). At Seaward Moss, no active insects were observed on the food plants during the day or night, despite similar canopy temperatures $\left(+3.4^{\circ} \mathrm{C}\right)$. Rather, insects were found in thick tufts of grass at the base of the L. scoparium. This suggests that $N$. 
annulata could utilize this microhabitat to avoid temperature extremes in the plant canopy, or perhaps to shelter from predators when the cold makes them less mobile. We cannot conclude that insects are not active on other nights in the winter, but, although diapause has not been observed in New Zealand insects (Dumbleton 1967), it is possible these individuals were quiescent. In Dunedin, not only did we observe several live nymphs and adults of both sexes, but also two copulating pairs at night, when temperatures were comparable to other sites $\left(+3.3^{\circ} \mathrm{C}\right)$. This suggests $N$. annulata is capable of continuous reproduction throughout the year, rather than mating seasonally, as is observed in many other insects (Kobayashi \& Osakabe 2009; Tauber et al. 1986).

We found individuals of Micrarchus during the winter at two of the three sites visited, including one montane and one lowland population. Micrarchus nov. sp. 1 was readily found at lowland site of Puhi Puhi, where a total of 20 individuals were observed, including several active at night, when the canopy temperature measured $+2.4^{\circ} \mathrm{C}$. Several individuals were also found at this site buried in the grass during the day, suggesting that they may use this habitat for protection, similar to $N$. annulata. However, as we also observed active individuals in the trees at night, this suggests they are sheltering at ground level during the day and moving into their host plants at night. We did not survey high altitude populations of Micrarchus nov. sp. 1 , so we are unable to determine at what life stage this species over-winters at increased elevations.

Live animals were also found in one of the two montane populations of Micrarchus nov. sp. 2 surveyed in July. At Sewell Peak, 10 individuals were found during day and night searches. Although canopy temperature measured during collection were only slightly cooler than some sites $\left(+2.5^{\circ} \mathrm{C}\right)$, most individuals were located at the base of L. scoparium plants, either in the leaf litter and grass, or compressed a few centimetres into the mud at the base of the plant stem. A single nymph found in the leaves of a small bush during the day was the only individual observed in the canopy.

Winter collection of Micrarchus nov. sp. 2 at Mt. Arthur was prevented by large snow drifts. This site appears to have significant snow cover for a large portion of the winter, as was observed by Salmon (1991) in his discussion of what is now Micrarchus nov. sp. 2. Here, buffering by the snow kept this site relatively warm for much of the winter (Figure 3 ) such that the temperature extremes experienced by the Mt. Arthur population are less extreme than at Sewell Peak, and presumably other montane sites with less insulating snow. If insects do remain under the snow (which we could not determine), then buffered temperatures would 
mean that selection for cold tolerance would be weaker relative to Sewell Peak or the montane populations of $N$. annulata.

\section{Conclusion}

271

We have found that a variety of life stages overwinter in the three montane species surveyed:

272 N. annulata, Micrarchus nov. sp. 1 and Micrarchus nov. sp. 2. There appears to be a

273 reduction in the winter population abundance, as has been observed in other alpine insects in

274 New Zealand (Sinclair et al. 2001). There was no clear relationship between altitude and mean temperature, but more freezing hours were recorded at high elevation. However, as both lowland and montane sites repeatedly experience sub-zero temperatures in winter, overwintering individuals in all populations must tolerate similar freezing conditions. Further investigation is now needed to determine how adults and nymphs survive freezing, and if that strategy is the same among stick insects species found in New Zealand.

\section{Acknowledgements}

We are grateful to Litza Coello, Mhari McFarlane, Lucy Shield, Clive Williams, Rich Leschen, Ana Ramon-Laca, Shelley Myers and Tony Jewell for field assistance, and two anonymous referees for comments that improved the manuscript. This project was supported by The Royal Society of New Zealand Marsden Fund (LCR0901), the Allan Wilson Centre for Molecular Ecology and Evolution, and Core funding for Crown Research Institutes from the Ministry of Business, Innovation and Employment's Science and Innovation Group. 


\section{References}

Buckley TR, Simon C. 2007. Evolutionary radiation of the cicada genus Maoricicada Dugdale (Hemiptera: Cicadoidea) and the origins of the New Zealand alpine biota. Biological Journal of the Linnean Society 91: 419-435.

Crosby TK, Dugdale JS, Watt JC. 1998. Area codes for recording specimen localities in the New Zealand subregion. New Zealand Journal of Zoology 25: 175-183.

Danks HV. 2007. How aquatic insects live in cold climates. Canadian Entomologist 139: 443471.

Dumbleton LJ. 1967. Winter dormancy in New Zealand biota and its paleoclimatic implications. New Zealand Journal of Botany 5: 211-222.

Dunning, L.T., A.B. Dennis, D.C. Park, B.J. Sinclair, R.D. Newcomb, T.R. Buckley. 2013. Identification of cold-responsive genes in a New Zealand alpine stick insect using RNA-Seq. Comparative Biochemistry and Physiology Part D: Genomics and Proteomics 8: 24-31.

Giese RL, Knauer KH. 1977. Ecology of the walking stick. Forest Science 23: 45-63.

Jewell T, Brock PD. 2002. A review of the New Zealand stick insects: new genera and synonymy, keys, and a catalogue. Journal of Orthoptera Research 11: 189-197.

Kobayashi T, Osakabe M. 2009. Pre-winter copulation enhances overwintering success of Orius females (Heteroptera: Anthocoridae). Applied Entomology and Zoology 44:4752.

Leschen RAB, Buckley TR, Hoare R. 2009. The use of tag-names and New Zealand taxonomy. New Zealand Entomologist 32:85-87.

O'Neill SB, Buckley TR, Jewell TR, Ritchie PA. 2009. Phylogeographic history of the New Zealand stick insect Niveaphasma annulata (Phasmatodea) estimated from mitochondrial and nuclear loci. Molecular Phylogenetics and Evolution 53: 523-536.

Otte D, Brock PD, Academy of Natural Sciences of P. 2005. Phasmida species file: catalog of stick and leaf insects of the world Published by the Insect Diversity Association at the Academy of Natural Sciences, Philadelphia.

R Development Core Team. 2012. R: A language and environment for statistical computing, R Foundation for Statistical Computing, Vienna, Austria.

Rochefort S, Berthiaume R, Hebert C, Charest M, Bauce E. 2011. Effect of temperature and host tree on cold hardiness of hemlock looper eggs along a latitudinal gradient. Journal of Insect Physiology 57: 751-759.

Salmon JT. 1991. The stick insects of New Zealand Reed, Auckland, New Zealand.

Sinclair BJ. 2001. Field ecology of freeze tolerance: interannual variation in cooling rates, freeze-thaw and thermal stress in the microhabitat of the alpine cockroach Celatoblatta quinquemaculata. Oikos 93: 286-293.

Sinclair BJ, Addo-Bediako A, Chown SL. 2003. Climatic variability and the evolution of insect freeze tolerance. Biological Reviews 78: 181-195.

Sinclair BJ, Lord JM, Thompson CM. 2001. Microhabitat selection and seasonality of alpine invertebrates. Pedobiologia 45: 107-120. 
Tauber MJ, Tauber CA, Masaki S. 1986. Seasonal adaptations of insects Oxford University Press. 411 p.

Vera A, Pastenes L, Veloso C, Mendez MA. 2012. Phylogenetic relationships in the genus Agathemera (Insecta: Phasmatodea) inferred from the genes 16S, COI and H3. Zoological Journal of the Linnean Society 165: 63-72.

Vermunt, B., Cuddington, K., Sobek-Swant, S., Crosthwaite, J., Barry, B. and B. Sinclair. 2012. Temperatures experienced by wood-boring beetles in the under-bark microclimate. Forest Ecology and Management 269: 149-157.

Wharton DA. 2011. Cold tolerance of New Zealand alpine insects. Journal of Insect Physiology 57: 1090-1095. 
343 Table 1: Location, two-letter land area codes (Crosby et al. 1998), elevation, coordinates, summary of 344 collections and caging. Sites with + are entirely parthenogenetic populations. Locales with heavy snow 345 that prevented July collections are marked with a *. Grey shaded boxes indicate locales where cages 346 were not placed. $\mathrm{F}=$ female, $\mathrm{M}=$ male and $\mathrm{N}=$ nymph.

\begin{tabular}{|c|c|c|c|c|c|c|}
\hline Site & Elevation & $\begin{array}{l}\text { Latitude, } \\
\text { Longitude }\end{array}$ & $\begin{array}{l}\text { April } 2011, \\
\text { total }\end{array}$ & $\begin{array}{l}\text { July } \\
2011 \\
\text { total } \\
\end{array}$ & $\begin{array}{l}\text { Caged, } \\
\text { April } \\
2011 \\
\end{array}$ & $\begin{array}{l}\text { Cage, July } \\
2011\end{array}$ \\
\hline \multicolumn{7}{|l|}{ Micrarchus nov. sp. 1} \\
\hline $\begin{array}{l}\text { Puhi Puhi Scenic } \\
\text { Reserve, KA }\end{array}$ & $290 \mathrm{~m}$ & $\begin{array}{l}-42.2397 \\
173.7528\end{array}$ & Not visited & $\begin{array}{l}12 \mathrm{~F}, 5 \\
\mathrm{M}, 3 \mathrm{~N}\end{array}$ & & \\
\hline \multicolumn{7}{|l|}{ Micrarchus nov. sp. 2} \\
\hline $\begin{array}{l}\text { Mt. Arthur, Kahurangi } \\
\text { National Park, NN }\end{array}$ & $1347 \mathrm{~m}$ & $\begin{array}{l}-41.1978, \\
172.7127 \\
\end{array}$ & Not visited & $0 *$ & & \\
\hline $\begin{array}{l}\text { Sewell Peak, the } \\
\text { Paparoa Range, BR }\end{array}$ & $736 \mathrm{~m}$ & $\begin{array}{l}-42.4052 \\
171.3424\end{array}$ & $\begin{array}{l}8 \mathrm{~F}, 8 \mathrm{M} \\
>5 \mathrm{~N}\end{array}$ & $\begin{array}{l}2 \mathrm{~F}, 5 \mathrm{M}, \\
3 \mathrm{~N}\end{array}$ & & \\
\hline \multicolumn{7}{|l|}{ Niveaphasma annulata } \\
\hline $\begin{array}{l}\text { Lake Ohau ski field } \\
\text { Rd., Mt. Sutton, MK }\end{array}$ & $810 \mathrm{~m}$ & $\begin{array}{l}-44.2418, \\
169.8036 \\
\end{array}$ & $\begin{array}{l}9 \mathrm{~F}, 11 \mathrm{M}, \\
34 \mathrm{~N}\end{array}$ & $\begin{array}{l}2 \mathrm{~F}, 1 \mathrm{M}, \\
4 \mathrm{~N}\end{array}$ & $\begin{array}{l}3 \mathrm{~F}, 7 \mathrm{M}, \\
15 \mathrm{~N}\end{array}$ & $3 \mathrm{~N}$ \\
\hline $\begin{array}{l}\text { Rastus Burn Scenic } \\
\text { Reserve, Remarkables, } \\
\text { CO+ }\end{array}$ & $1031 \mathrm{~m}$ & $\begin{array}{l}-45.0267 \\
168.7852\end{array}$ & 0 & $0 *$ & & \\
\hline $\begin{array}{l}\text { Nevis Rd., Carrick } \\
\text { Range, Bannockburn, } \\
\text { CO+ }\end{array}$ & $604 \mathrm{~m}$ & $\begin{array}{l}-45.2594 \\
169.2112\end{array}$ & $2 \mathrm{~F},>20 \mathrm{~N}$ & $0 *$ & & \\
\hline $\begin{array}{l}\text { Malvern St., Dunedin, } \\
\text { DN }\end{array}$ & $49 \mathrm{~m}$ & $\begin{array}{l}-45.8501 \\
170.5044 \\
\end{array}$ & Not visited & $\begin{array}{l}3 \mathrm{~F}, 15 \\
\mathrm{M}, 4 \mathrm{~N}\end{array}$ & & \\
\hline $\begin{array}{l}\text { Old Coach Rd. Track, } \\
\text { Papatowai, SL }\end{array}$ & $1 \mathrm{~m}$ & $\begin{array}{l}-46.5529 \\
169.4746\end{array}$ & $\begin{array}{l}2 \mathrm{~F},>30 \mathrm{~N} \\
\& \mathrm{M}\end{array}$ & 0 & & \\
\hline $\begin{array}{l}\text { Seaward Moss } \\
\text { Conservation Area, } \\
\text { Invercargill, SL }\end{array}$ & $9 \mathrm{~m}$ & $\begin{array}{l}-46.5419 \\
168.4339\end{array}$ & $\begin{array}{l}16 \mathrm{~F}, 18 \mathrm{M}, \\
22 \mathrm{~N}\end{array}$ & $\begin{array}{l}4 \mathrm{~F}, 1 \\
\mathrm{M}, 2 \mathrm{~N}\end{array}$ & $\begin{array}{l}3 \mathrm{~F}, 5 \mathrm{M}, \\
6 \mathrm{~N}\end{array}$ & $3 \mathrm{~F}, 1 \mathrm{M}$ \\
\hline
\end{tabular}


349 Table 2: Average frequency of observations of temperatures below $0^{\circ} \mathrm{C}$ at sites containing

350 Micrarchus. Observations were made every 1.5 hours, and the average of three data loggers is

351 presented. Localities are detailed in Table 1. Missing data are indicated by a dash (-).

352

\begin{tabular}{lcccccc}
\hline Month & Sewell Peak & Sewell Peak & Mt. Arthur & Mt. Arthur & Puhi Puhi & Puhi Puhi \\
\hline Habitat & Canopy & Litter & Canopy & Litter & Canopy & Litter \\
\hline January & 0 & 0 & 0 & 0 & 0 & 0 \\
February & 0 & 0 & 0 & 0 & - & - \\
March & 0 & 0 & 2.0 & 0 & - & - \\
April & 0 & 0 & 18.0 & 9.0 & - & - \\
May & 1.0 & 0 & 27.0 & 8.0 & - & - \\
June & 0.3 & 0 & 59.0 & 36.0 & - & - \\
July & 33.7 & 33.5 & 106.0 & 36.0 & 20.3 & 6.0 \\
August & 48.3 & 57.0 & 67.0 & 36.0 & 42.0 & 19.0 \\
September & 11.3 & 6.0 & 135.0 & 29.0 & 6.7 & 0.7 \\
October & 0 & 0 & 29.0 & 9.0 & 5.7 & 1.0 \\
November & 6.3 & 1.5 & 26.0 & 3.0 & 0 & 0 \\
December & 0 & 0 & 0 & 0 & 0 & 0 \\
\hline
\end{tabular}

353

354

355 
Table 3: Average frequency of observations of temperatures below $0^{\circ} \mathrm{C}$ at sites containing

357 Niveaphasma annulata. Each measure represents a 1.5 hourly recording below $0^{\circ} \mathrm{C}$ and is the average 358 of three data loggers. Localities are detailed in Table 1.

\begin{tabular}{lccccccccc}
\hline Month & $\begin{array}{l}\text { Coach } \\
\text { Rd. }\end{array}$ & $\begin{array}{l}\text { Coach } \\
\text { Rd. }\end{array}$ & $\begin{array}{l}\text { Seaward } \\
\text { Moss }\end{array}$ & $\begin{array}{l}\text { Seaward } \\
\text { Moss }\end{array}$ & Dunedin & $\begin{array}{l}\text { Nevis } \\
\text { Rd. }\end{array}$ & $\begin{array}{l}\text { Nevis } \\
\text { Rd. }\end{array}$ & Remarkables & Ohau \\
\hline Habitat & Canopy & Litter & Canopy & Litter & Ground & Canopy & Litter & Ground & Ground \\
\hline January & 0.4 & 0 & 2.5 & 2.0 & 0 & 0.7 & 0 & 0 & 0 \\
February & 0.8 & 0 & 3.0 & 1.7 & 0 & 0 & 0 & 0 & 0 \\
March & 1.2 & 0 & 7.0 & 3.3 & 0 & 0 & 0 & 0 & 0 \\
April & 5.0 & 0 & 29.5 & 25.7 & 0 & 20.0 & 12.3 & 4.3 & 1.3 \\
May & 2.0 & 0 & 2.0 & 1.3 & 0 & 10.7 & 5.3 & 2.0 & 0.0 \\
June & 12.6 & 0.3 & 58.0 & 45.0 & 0 & 41.0 & 32.0 & 26.7 & 3.0 \\
July & 4.2 & 0 & 37.5 & 33.7 & 5.5 & 223.0 & 185.7 & 39.3 & 127.3 \\
August & 8.4 & 0 & 35.0 & 24.3 & 6.0 & 129.0 & 128.3 & 79.7 & 78.0 \\
September & 4.4 & 0 & 14.0 & 11.3 & 0 & 57.0 & 52.3 & 17.7 & 11.0 \\
October & 4.0 & 0 & 28.0 & 24.3 & 0 & 11.7 & 9.0 & 0.7 & 0.3 \\
November & 4.4 & 0 & 10.0 & 5.0 & 0 & 11.3 & 7.7 & 2.0 & 5.7 \\
December & 4.8 & 0 & 4.0 & 1.7 & 0 & 0 & 0 & 0 & 0 \\
\hline
\end{tabular}

360

361

362 
(a) An iButton thermochron data logger and plastic housing. The data logger is approximately

(b) A cage placed at Seaward Moss surrounded by Leptospermum scoparium host plants. The cage was constructed around a small L. scoparium, contained a known number of insects (Table 1), and was left in place from April to July 2011.

Figure 2: Map of collections sites containing Niveaphasma annulata (circles) and Micrarchus sp. (squares), coordinates are degrees S and E (WGS 1984 datum) and are detailed in Table 1.

Figure 3: Summary of mean monthly temperature recordings for sites containing Micrarchus $s p$. (large circles). Vertical lines span the mean daily maximum and mean daily minimum temperature for each month, and outer points indicate extreme monthly temperatures. Paired points for each month represent recordings from the plant canopy (open circles) and the leaf litter (dark circles).

Figure 4: Summary of mean monthly temperature recordings for sites containing Niveaphasma annulata (large circles). Vertical lines the span the mean daily maximum and mean daily minimum for each month, and outer points indicate extreme monthly temperatures. Paired points for each month represent recordings from the plant canopy (open circles) and the leaf litter (dark circles). Sites at which solitary data loggers were placed close to the ground, but not in litter, are represented by black squares. 

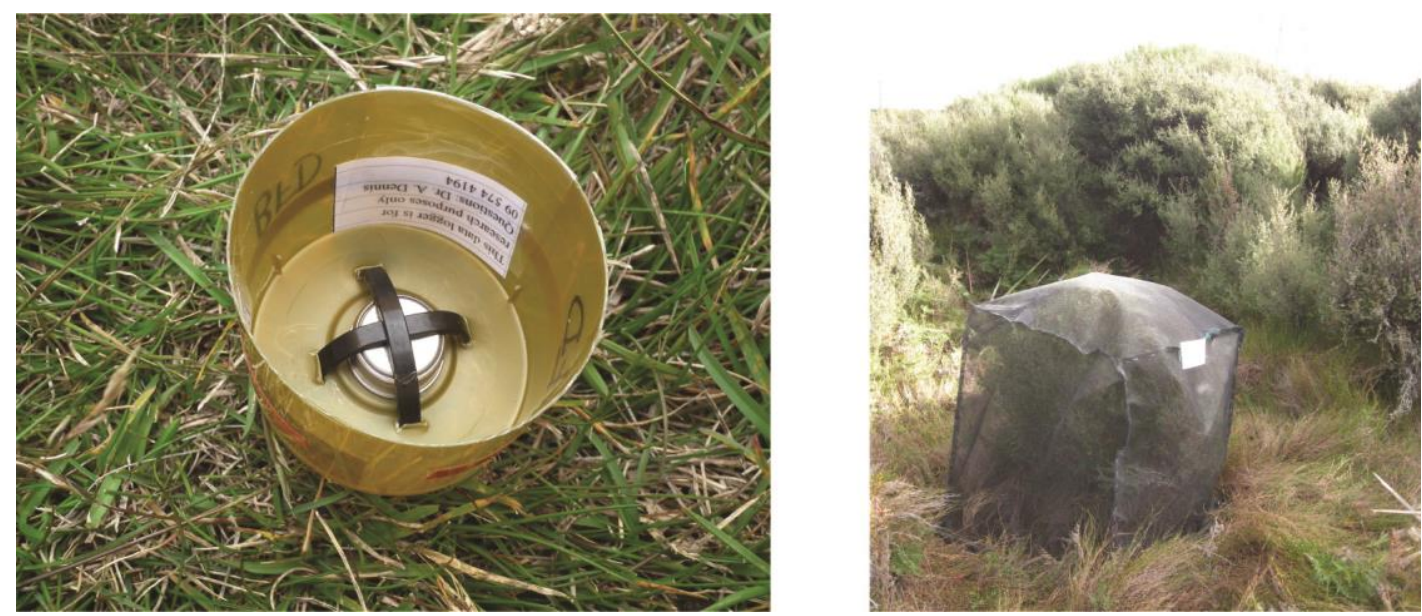

394

395

396

397

398

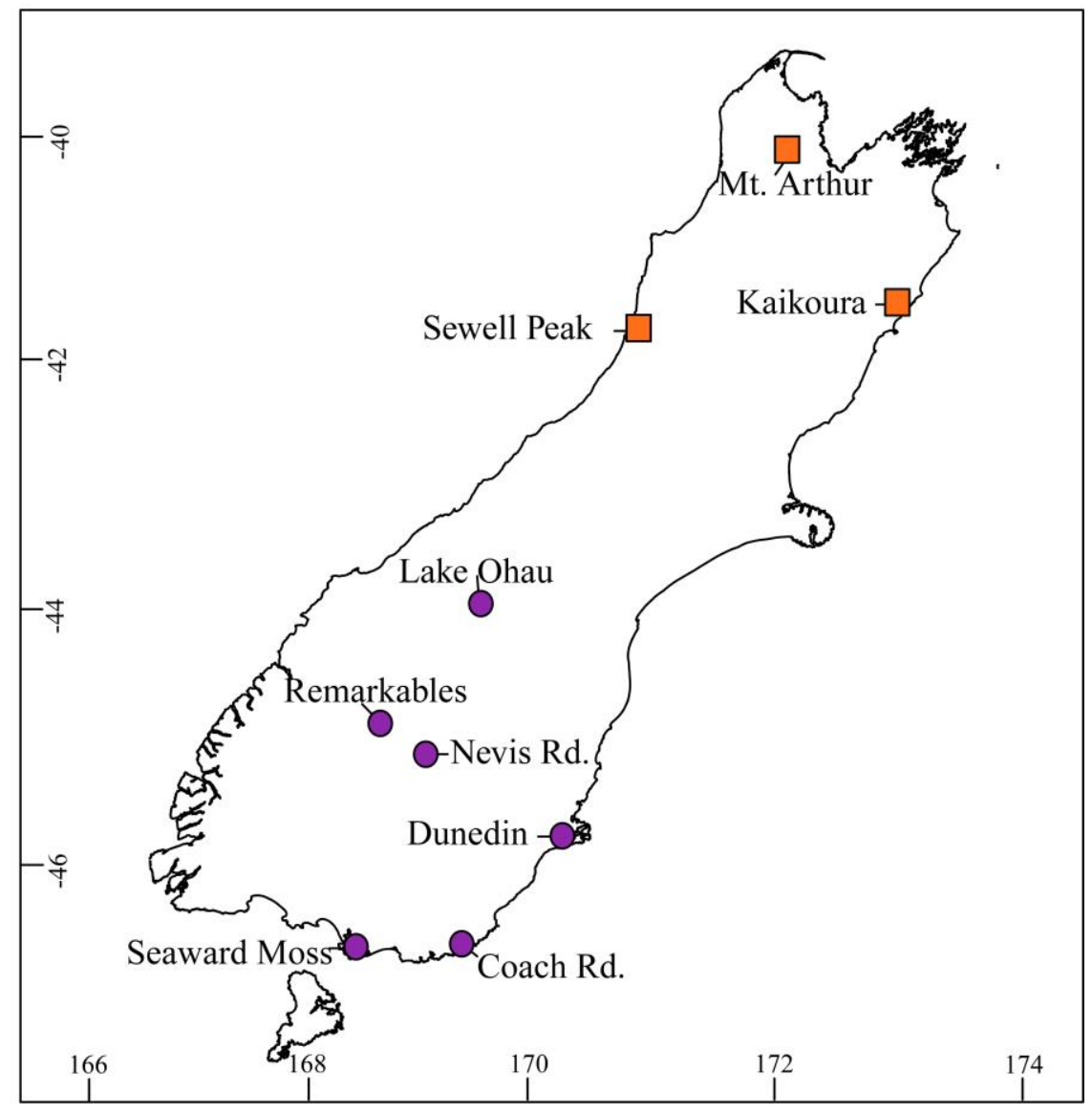

399

400 

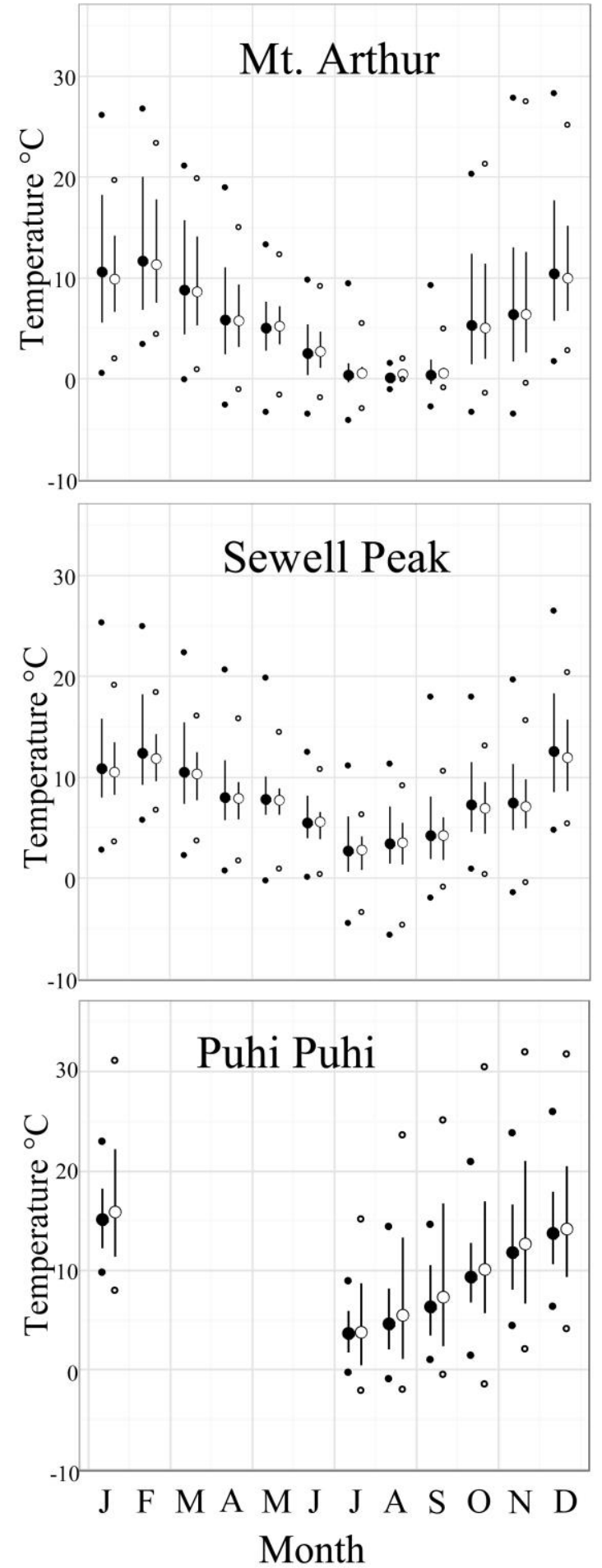

402 

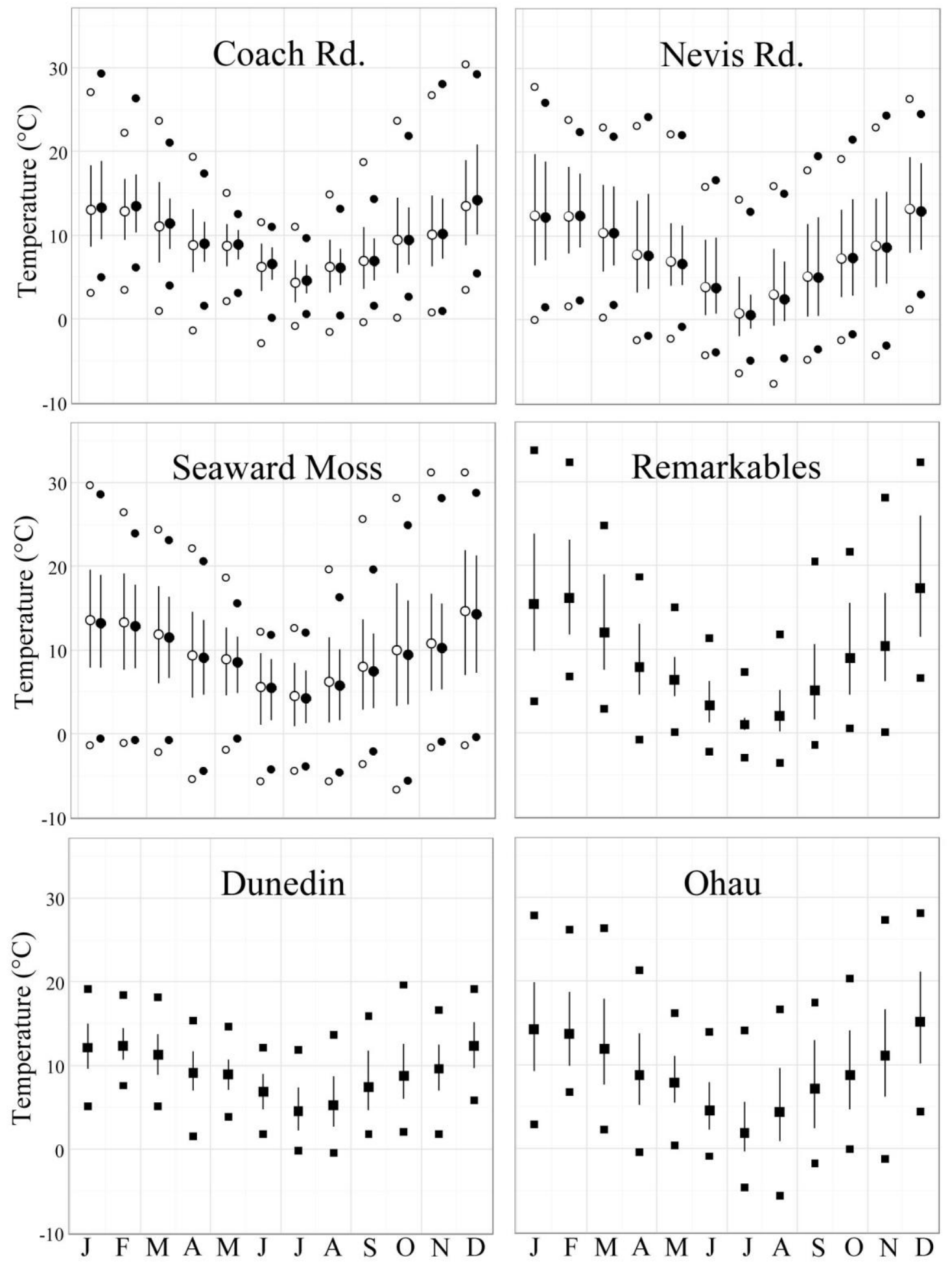

Month 